\title{
A summary of growth rates of thoroughbreds in Kentucky
}

\author{
J. D. Pagan', S. G. Jackson' and S. Caddel2 \\ 1Kentucky Equine Research, Inc. Versailles, Kentucky \\ 2Hallway Feeds, Lexington, KY
}

\begin{abstract}
Summary
Over a three year period (1993, 1994, and 1995), a total of 350 Thoroughbred colts and 350 Thoroughbred fillies in Central Kentucky were weighed monthly on a portable electronic scale through 18 months of age. Wither height and condition score were also measured in about half of the foals. In order to estimate mature body size in these horses, 472 brood mares were weighed 60 to 90 days after foaling. In addition, 25 Thoroughbred breeding stallions were also weighed. The average body weight of the brood mares equaled $570 \mathrm{~kg}$ and the average weight of the stallions equaled $580 \mathrm{~kg}$. At 14 days of age, colts and fillies weighed an average of 77.7 and $76.1 \mathrm{~kg}$ and had average heights of 107.3 and $106.3 \mathrm{~cm}$, respectively. Colts were heavier and taller than fillies throughout the study and at 490 days averaged $9.9 \mathrm{~kg}$ heavier $(427.8 \mathrm{~kg}$ vs $418.0 \mathrm{~kg})$ and $1.6 \mathrm{~cm}$ taller $(153.4 \mathrm{~cm}$ vs $151.8 \mathrm{~cm})$. The greatest difference in condition score between sexes occurred at four months of age when the fillies had an average score of 6.48 and the colts had a score of 6.0.

Compared to March foals, foals born in January and February were $6.8 \mathrm{~kg}$ lighter at 14 days of age. They remained smaller, by as much as $15.3 \mathrm{~kg}$ at 72 days of age, until about 9 months of age when they averaged about the same as the March foals. April and May foals were larger at 14 days of age than March foals, and remained slightly heavier until 6 months of age. Average daily gain between the four groups was similar until about 7 months of age. ADG averaged $1.5-1.7 \mathrm{~kg} / \mathrm{d}$ during the first month and declined linearly to about $.70-.80 \mathrm{~kg} / \mathrm{d}$ at 7 months of age. After 7 months of age, ADG tended to be more variable and by 12 months, ADG was very different between the different months of birth. Foal growth rates were reduced during the winter months, regardless of when the foals were born and increased during April and May of the foal's yearling year. Growth rate in these yearlings was more a function of season of the year than age.
\end{abstract}

keywords: $\quad$ foal, growth rate, body weight, body size

\begin{abstract}
Übersicht zu den Wachstumsraten von Vollblutpferden in Kentucky
Insgesamt 350 Vollbluthengst- und Vollblutstutfohlen wurden in Kentucky in einem Zeitraum von drei Jahren (1993-1995) bis zum Alter von 18 Monaten auf einer tragbaren elektronischen Waage monatlich gewogen. Bei ungefähr der Hälfte der Fohlen wurde darüberhinaus die Widerristhöhe und die Körperkondition festgestellt. Um die Körpermaße adulter Pferde zu schätzen, wurden 472 Zuchtstuten 60-90 Tage nach dem Abfohlen und zusätzlich 25 Vollblutzuchthengste gewogen. Die durchschnittliche Körpermasse der Zuchtstuten betrug $570 \mathrm{~kg}$, die der Hengste $580 \mathrm{~kg}$. Im Alter von 14 Tagen wogen Hengst- und Stutfohlen im Mittel 77,7 bzw. 76,1 kg und hatten eine durchschnittliche Höhe von 107,3 bzw. 106,3 cm. Hengstfohlen waren durchschnittlich größer und schwerer als Stutfohlen; mit 490 Tagen im Mittel 9,9 kg schwerer $\{427,8 \mathrm{~kg}$ vs. $418,0 \mathrm{~kg})$ und $1,6 \mathrm{~cm}$ größer $(153,4 \mathrm{~cm}$ vs. $151,8 \mathrm{~cm})$. Hinsichtlich der Konditionsbewertung trat der größte Unterschied zwischen den Geschlechtern im Alter von 4 Monaten auf. Zu diesem Zeitpunkt besaßen Stutfohlen eine durchschnittliche Punktzahl von 6,48 und Hengstfohlen von 6,0. Im Vergleich zu den im März geborenen Fohlen waren im Januar und Februar geborene Fohlen im Alter von 14 Tagen 6,8 kg leichter. Bis zum Alter von 9 Monaten, in dem sie im Mittel den Fohlen vom März entsprachen, blieben sie, bis zu 15,3 kg im Alter von 72 Tagen, leichter. Im Alter von 14 Tagen waren Fohlen von April und Mai größer als Märzfohlen und blieben bis zum Alter von 6 Monaten geringgradig schwerer. Die durchschnittliche Tageszunahme der 4 Gruppen verlief bis zum Alter von 7 Monaten vergleichsweise ähnlich. Vom ersten Monat bis zum Alter von 7 Monaten fiel die mittlere Tageszunahme von 1,5-1,7 kg/Tag auf 0,7-0,8 kg/Tag ab. Nach 7 Monaten schien die durchschnittliche Tageszunahme schwankender zu sein und war im Alter von 12 Monaten bei den Fohlen der verschiedenen Geburtsmonate sehr unterschiedlich. In den Wintermonaten war die Wachstumsrate der Fohlen unabhängig von ihrem Geburtszeitpunkt herabgesetzt und stieg im April und Mai bei den Jährlingen an. Die Wachstumsrate dieser Jährlinge stellte sich mehr als eine Funktion der Jahreszeit als des Alters dar.
\end{abstract}

Schlüsselwörter: Fohlen, Wachstumsrate, Körpermasse, Körpermaße

\section{Introduction}

Nutrient requirements for growing horses are usually based on age, body weight, mature body size and growth rate (average daily gain). For instance, the 1989 NRC calculates the digestible energy (DE) requirement of growing horses using a regression equation that incorporates age, body weight and average daily gain. Other nutrients are then calculated based on either the DE requirement, the foal's body weight, average daily gain or estimated dry matter intake which is based on body weight. Ideally, to accurately determine the nutrient requirements of an individual, its body 
weight and growth rate should be measured. Unfortunately, most young growing horses are not weighed on a regular basis and their body weights must be estimated based on their age and predicted mature body size.

Hintz et al. (1979) summarized growth data from 1,992 Thoroughbred foals raised at a single Canadian farm over an 18 year period. The effect of age of dam, year and month of birth and sex of foal were evaluated. These data have been accepted universally as the typical growth patterns for Thoroughbred foals. It has not been adequately established, however, whether these growth rates are representative for Thoroughbred foals raised in other areas. Therefore, the following growth data were compiled for a large number of Thoroughbred foals raised under commercial conditions in Kentucky.

\section{Methods}

Over a three year period (1993, 1994, and 1995), a total of 350 Thoroughbred colts and 350 Thoroughbred fillies in Central Kentucky were weighed monthly on a portable electronic scale (Equimetrics, Inc., Redfield, AR) through 18 mature horses using a scoring system of 1 through 9 to estimate fat deposition. In order to estimate mature body size in these horses, 472 brood mares were weighed 60 to 90 days after foaling. In addition, 25 Thoroughbred breeding stallions were also weighed.

\section{Results and discussion}

Growth rates of Kentucky colts and fillies are shown in table 1. Fillies were $1.6 \mathrm{~kg}$ lighter and $1 \mathrm{~cm}$ shorter than colts at 14 days of age. By 127 days of age fillies were on average $3.4 \mathrm{~kg}$ lighter and $0.2 \mathrm{~cm}$ shorter than the colts. By 350 days of age, colts averaged $14.0 \mathrm{~kg}$ heavier and $1.5 \mathrm{~cm}$ taller than fillies. By 490 days, the difference in body weight between colts and fillies in the present study had been reduced to $9.9 \mathrm{~kg}$

\section{Condition score}

The average condition score of the foals at 1-18 months of age is summarized in figure 1. Fillies tended to have higher condition scores throughout this time period. The greatest difference in condition score between sexes occurred at

Tab. 1: Growth rates of fillies and colts in Central Kentucky

Zunahmen bei Stut- und Hengstfohlen in Kentucky

\begin{tabular}{|c|c|c|c|c|c|c|c|c|}
\hline $\begin{array}{c}\text { average } \\
\text { days of } \\
\text { age }\end{array}$ & $\begin{array}{c}\text { colts } \\
\mathrm{bw} \\
(\mathrm{kg})\end{array}$ & $\begin{array}{c}\text { fillies } \\
\mathrm{bw} \\
(\mathrm{kg})\end{array}$ & $\begin{array}{c}\text { colts } \\
\mathrm{adg} \\
(\mathrm{kg} / \mathrm{d})\end{array}$ & $\begin{array}{c}\text { fillies } \\
\mathrm{adg} \\
(\mathrm{kg} / \mathrm{d})\end{array}$ & $\begin{array}{c}\text { colts } \\
\mathrm{ht} \\
(\mathrm{cm})\end{array}$ & $\begin{array}{c}\text { fillies } \\
\mathrm{ht} \\
(\mathrm{cm})\end{array}$ & $\begin{array}{c}\text { colts } \\
\text { condition } \\
\text { score }\end{array}$ & $\begin{array}{c}\text { fillies } \\
\text { condition } \\
\text { score }\end{array}$ \\
\hline 14 & 77.7 & 76.1 & - & - & 107.3 & 106.3 & 5.7 & 6.0 \\
\hline 43 & 116.3 & 115.1 & 1.38 & 1.34 & 115.7 & 115.5 & 6.2 & 6.4 \\
\hline 72 & 149.5 & 148.5 & 1.20 & 1.19 & 122.6 & 121.8 & 6.2 & 6.3 \\
\hline 99 & 182.1 & 178.6 & 1.14 & 1.11 & 127.3 & 127.1 & 6.0 & 6.5 \\
\hline 127 & 208.8 & 207.9 & 1.01 & 1.01 & 129.8 & 130.3 & 5.8 & 5.9 \\
\hline 155 & 233.6 & 230.2 & 0.89 & 0.84 & 133.5 & 132.5 & 5.5 & 5.7 \\
\hline 183 & 255.9 & 250.7 & 0.80 & 0.75 & 135.8 & 134.7 & 5.4 & 5.6 \\
\hline 212 & 277.1 & 271.0 & 0.75 & 0.71 & 138.2 & 137.4 & 5.5 & 5.5 \\
\hline 240 & 295.1 & 287.3 & 0.68 & 0.60 & 140.0 & 139.4 & 5.4 & 5.5 \\
\hline 267 & 309.1 & 300.6 & 0.55 & 0.48 & 141.8 & 140.7 & 5.4 & 5.4 \\
\hline 296 & 322.0 & 311.0 & 0.43 & 0.40 & 144.2 & 142.5 & 5.3 & 5.4 \\
\hline 323 & 335.1 & 322.5 & 0.40 & 0.35 & 145.4 & 144.0 & 5.4 & 5.4 \\
\hline 350 & 349.2 & 335.2 & 0.43 & 0.39 & 147.0 & 145.5 & 5.3 & 5.4 \\
\hline 378 & 362.5 & 350.1 & 0.45 & 0.51 & 148.3 & 146.7 & 5.4 & 5.5 \\
\hline 406 & 378.9 & 367.9 & 0.52 & 0.60 & 150.2 & 148.2 & 5.5 & 5.7 \\
\hline 435 & 396.2 & 388.9 & 0.62 & 0.65 & 150.8 & 149.6 & 5.5 & 5.8 \\
\hline 462 & 414.2 & 407.9 & 0.59 & 0.60 & 152.5 & 151.5 & 5.6 & 5.8 \\
\hline 490 & 427.8 & 418.0 & 0.55 & 0.54 & 153.4 & 151.8 & 5.7 & 5.8 \\
\hline
\end{tabular}

months of age. Wither height and condition score were also measured in about half of the foals. Condition score was based on the system developed by Henneke et al (1981) for four months of age when the fillies had an average score of 6.48 and the colts had a score of 6.0. These condition scores are considered moderate to fleshy according to the 


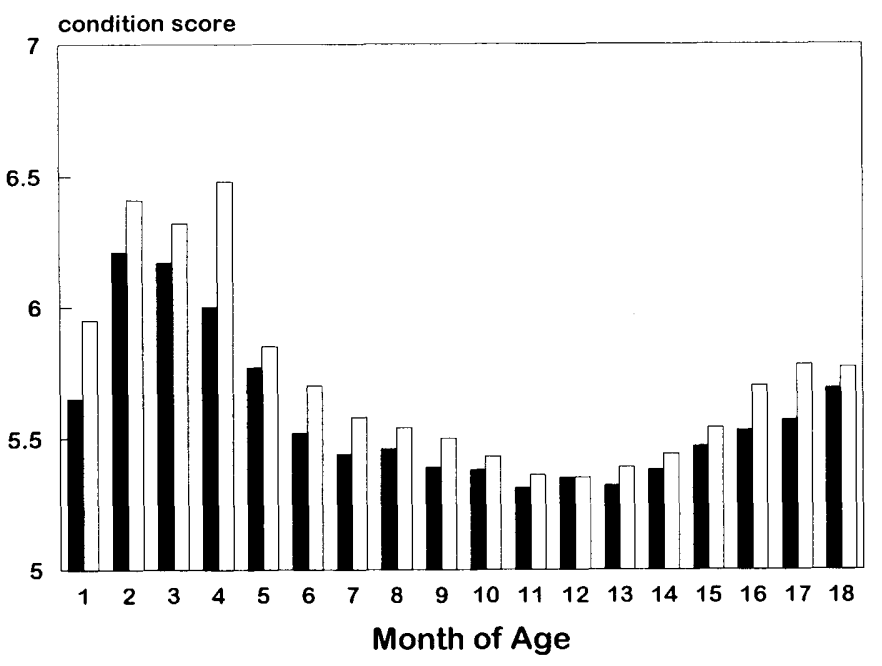

Fig. 1: Condition score in Thoroughbred foals (colts vs. Fillies) Körperkondition bei Vollblutfohlen (Hengstfohlen gegenüber Stutfohlen)

colts, $\square$ fillies age when they averaged about the same as the March foals.

April and May foals were larger at 14 days of age than March foals, and remained slightly heavier until 6 months of age. Figure 2 summarizes average daily gain $(\mathrm{kg} / \mathrm{d})$ in the different groups as a function of age. Average daily gain between the four groups was similar until about 7 months of age. ADG averaged 1.5-1.7 kg/d during the first month and declined linearly to about $.70-.80 \mathrm{~kg} / \mathrm{d}$ at 7 months of age. After 7 months of age, ADG tended to be more variable and by 12 months, ADG was very different between the different groups. This variability can be explained, however, by the season of the year in which each group reached a particular age. ADG has been regraphed in figure 3 as a function of the month in which a weight was taken rather than as a function of days of age. Foal growth rates were reduced during the winter months, regardless of when the foals were born and increased during April and May of the foal's yearling year. Growth rates during these months were remarkably similar regardless of age. Each group of foals experienced their slowest growth during January, February

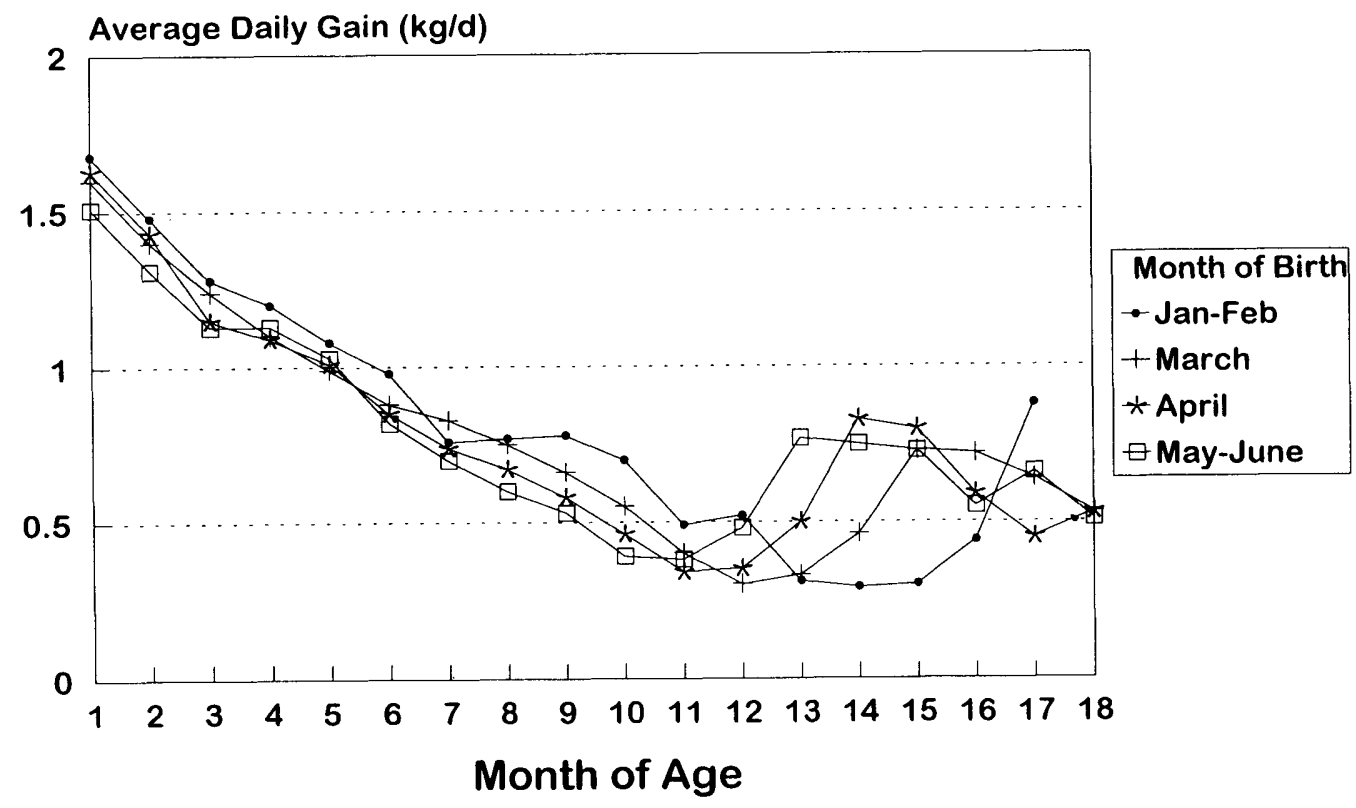

Fig. 2: Growth rate of foals (effect of month of birth)

Zunahmen bei Fohlen (Einfluß des Geburtsmonates)

Henneke scoring system. By twelve months of age the condition scores of the colts and fillies had dropped to 5.3 and 5.4 , respectively. Both sexes increased condition score slightly from 14 to 18 months.

\section{Effect of month of birth}

The foals were divided into 4 groups based on the month that they were born. These groups consisted of January and February foals (16.9\%), March foals (35.7\%), April foals $(32.5 \%)$ and May and June foals $(21.4 \%)$. Compared to March foals, foals born in January and February were 6.8 $\mathrm{kg}$ lighter at 14 days of age. They remained smaller, by as much as $15.3 \mathrm{~kg}$ at 72 days of age, until about 9 months of and March. During the spring months of April and May, each group of foals increased their ADG with peak gains occurring in May.

These data clearly demonstrate that growth rate in these yearlings is more a function of season of the year than age. These changes in growth rate closely follow changes in temperature and pasture growth in Kentucky. Most foals in Kentucky are raised in large paddocks with a great deal of available forage. During April and May, pasture growth is quite rapid. Supplemental grain intake is generally not greatly reduced during this time and growth rate accelerates as a result of increased caloric intake from forage. Assuming that grain intake remains constant and pasture con- 
Average Daily Gain (kg/d)

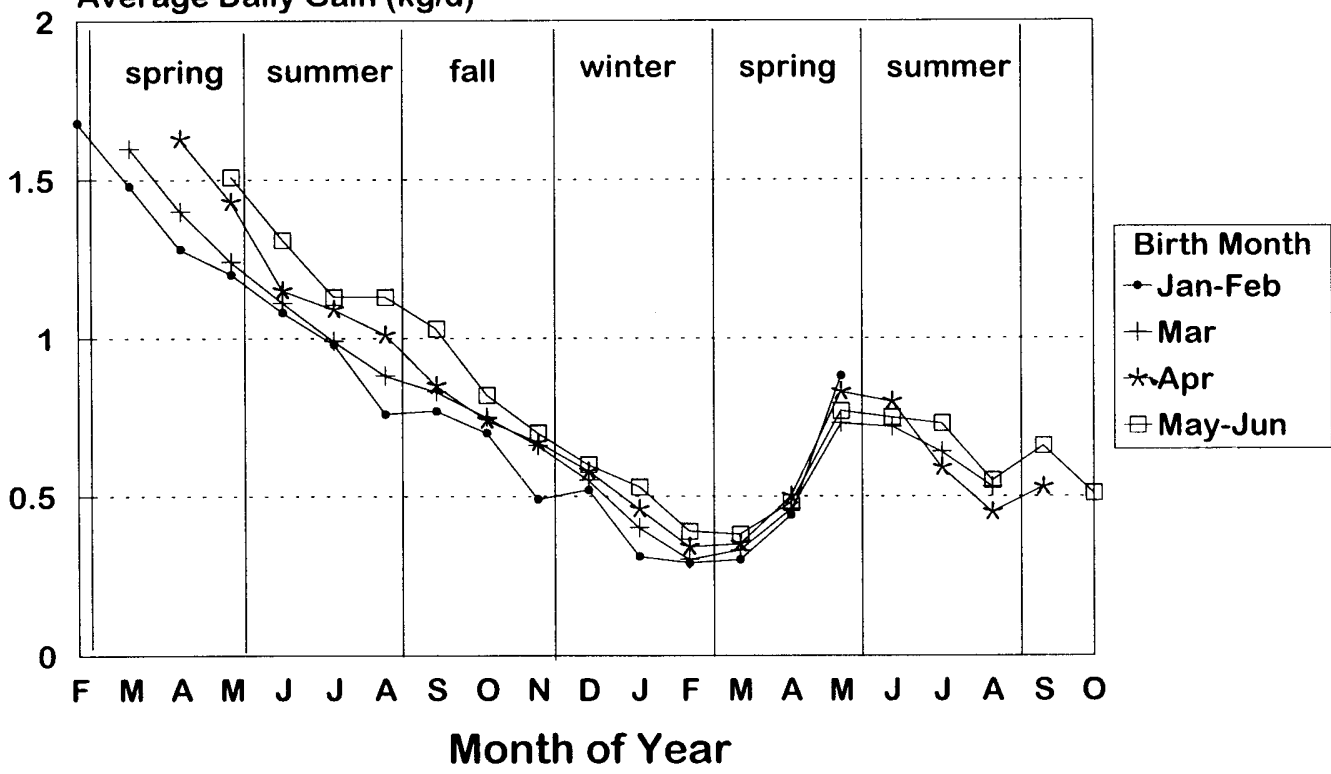

Fig. 3: Growth rates of foals (effect of season)

Zunahmen bei Fohlen (Einfluß der Jahreszeit)

tains about 9.2 MJ DE/kg DM, then these yearlings would need to consume about 3.25 additional $\mathrm{kg}$ of pasture DM per day in May to increase their ADG from .35 kg during the winter to about $.8 \mathrm{~kg} / \mathrm{d}$. This increase in dry matter intake would equal about .75\%-1.0\% of BW per day.

A comparison of body weight and height between Kentucky foals and Canadian foals born in March is shown in figures 4, 5 and 6 . In figure 4 the Kentucky foals' weights and heights are shown as a percentage of the Canadian foals. Kentucky foals were slightly taller (101.2) and heavier

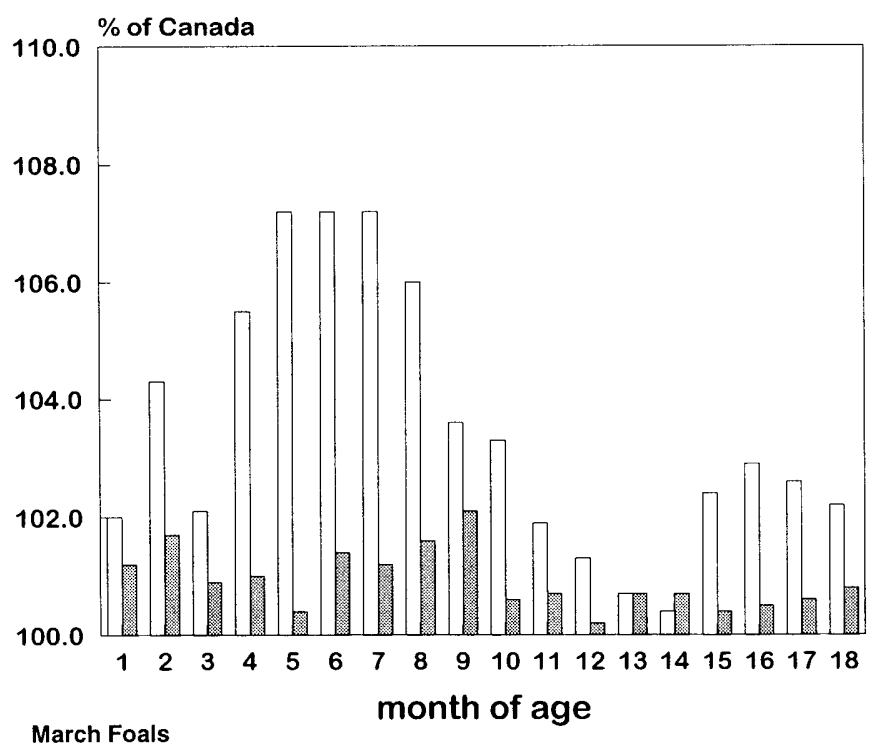

Fig. 4: Comparison of body weight and height of Kentucky and Canadian foals (as a \% of Canadian average)

Vergleich des Körpergewichtes und der Körpergröße bei Fohlen aus Kentucky und Kanada (in \% des kanadischen Mittels)

$\square$ body weight, $\mathbf{\square}$ height

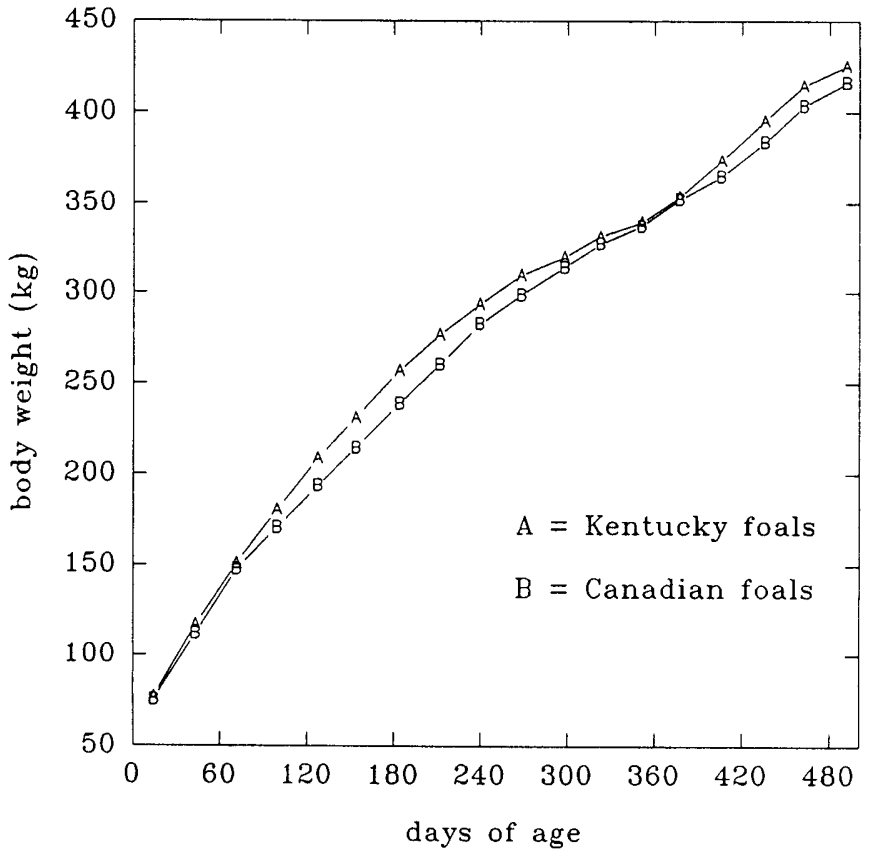

Fig. 5: Body weight $(\mathrm{kg})$ in Kentucky and Canadian foals (average of March foals)

Körpergewicht $(\mathrm{kg})$ bei Fohlen aus Kentucky und Kanada (Mittel der im März geborenen Fohlen)

$(102.0 \%)$ at 14 days of age. From 6 to 9 months of age, the Kentucky foals grew from 1.7 to $3.0 \mathrm{~cm}$ taller. These foals were also heavier from 4 to 10 months of age. At 6 months of age, the Kentucky foals averaged $107.2 \%$ of the Canadian body weight. By 12 months of age, the two groups had similar heights and weights. The Kentucky foals became heavier at 15 and 16 months, the age that coincided with rapid spring pasture growth in Kentucky.

The difference in body weights seen between these two groups of March foals could be the result of several factors. 


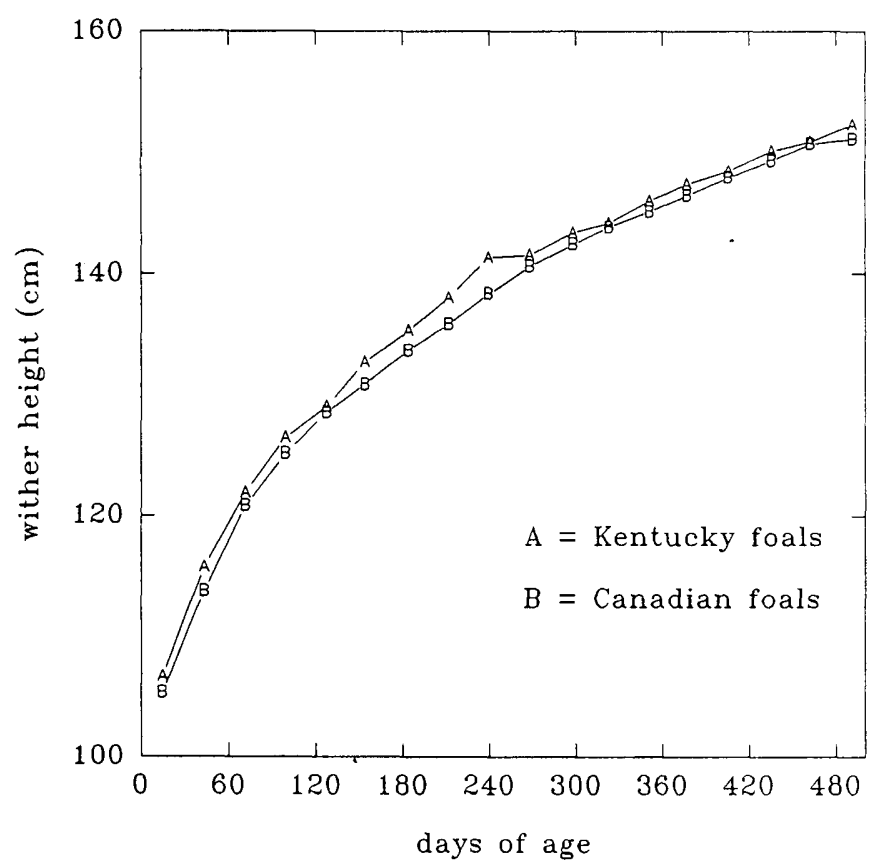

Fig. 6: Wither heights $(\mathrm{cm})$ in Kentucky and Canadian foals (average of March foals)

Widerristhöhe $(\mathrm{cm})$ bei Fohlen aus Kentucky und Kanada (Mittel der im März geborenen Fohlen)

First, the foals in Canada were weaned at 3 months of age while Kentucky foals are not usually weaned until they are 5-6 months old. These foals therefore had access to milk as well as grain and pasture for a longer period of time. At 6 months of age, March foals in Kentucky have access to high quality fall pasture. This forage remained lush and abundant until November when the foals are 10 months of age. Fall pasture in Ontario is not as abundant and temperatures begin to drop much earlier than in Kentucky.

\section{Mature body weights}

The average body weight of 472 brood mares 70 days post foaling equaled $570 \mathrm{~kg}$. The average weight of 25 breeding stallions equaled $580 \mathrm{~kg}$. From these data, an average mature weight of $575 \mathrm{~kg}$ seems reasonable. The 1989 NRC provides tables of nutrient requirements for horses with 500 and $600 \mathrm{~kg}$ mature body weights. Interpolating between these tables, weanlings with a mature BW of $575 \mathrm{~kg}$ would be expected to weigh 194 and $238 \mathrm{~kg}$ at 4 and 6 months of age, respectively. Four month old foals are expected to gain $.96 \mathrm{~kg} / \mathrm{d}$ and 6 month old foals are expected to gain between $.725 \mathrm{~kg} / \mathrm{d}$ and $.925 \mathrm{~kg} / \mathrm{d}$. The Kentucky foals averaged $7 \mathrm{~kg}$ heavier $(201 \mathrm{~kg})$ and gained $1.0 \mathrm{~kg} / \mathrm{d}$ at 4 months of age and weighed $12 \mathrm{~kg}$ more $(250 \mathrm{~kg})$ and gained $.77 \mathrm{~kg} / \mathrm{d}$ at 6 months of age. Thus, ADG was similar to values given by the NRC while body weight was $3-5 \%$ heavier.

At 12 and 18 months of age, the NRC would estimate that yearlings with a mature BW of $575 \mathrm{~kg}$ would equal 362.5 $\mathrm{kg}$ and $456 \mathrm{~kg}$, respectively. These yearlings would be expected to gain between .62-.71 kg/d at 12 months and .42 $\mathrm{kg} / \mathrm{d}$ at 18 months of age. Kentucky yearlings weighed an average of $348 \mathrm{~kg}$ and had an ADG of $.41 \mathrm{~kg} / \mathrm{d}$ at 12 months and weighed $445 \mathrm{~kg}$ and gained an average of $.425 \mathrm{~kg} / \mathrm{d}$ at 18 months of age. The Kentucky yearlings were $96 \%$ and $98 \%$ of the weights estimated by the NRC for 12 and 18 month yearlings and their 12 month ADG was only about $61 \%$ of that estimated by the NRC. It should be noted, however, that 12 months of age was before the average age at which rapid growth occurred in response to spring pasture growth. During this time (at about 14 months of age), ADG equaled about $.75 \mathrm{~kg} / \mathrm{d}$.

\section{Conclusion}

Thoroughbred foals raised in Kentucky grew faster from 4 to 9 months of age than foals raised in Ontario, Canada. These differences in growth were probably related to a later weaning time and abundant fall pasture in Kentucky compared to Canada. By 12 months of age, height and weight differences between the two groups had disappeared. Since rapid growth and excess body weight have been implicated as possible causes of skeletal disorders in foals, this extra growth in the Kentucky foals during the fall months is probably not desirable. Extra weight gain could be controlled by earlier weaning and by reducing supplemental grain intake as pasture becomes more available. Monthly weight monitoring can be used to signal the onset of this excessive weight gain. Average daily gain in yearlings was affected more by season than age. All of the foals experienced accelerated growth in the spring as pasture growth increased. Again, this accelerated growth can be identified by regular weighing and controlled by reductions in supplemental grain intake.

The weights and growth rates used by the NRC to calculate nutrient requirements for foals are generally accurate for Thoroughbred foals when seasonal variations in growth rate are taken into consideration.

\section{References}

Henneke, D. R., Potter, G. D. and Kreider, J. L. (1981): A condition score relationship to body fat content of mares during gestation and lactation. In: Proc. $7^{\text {th }}$ ENPS. Warrenton, Va pp 105-110.

Hintz, H. F., Hintz, R. L., and Van Vleck, L. D. (1979): Growth rate of Thoroughbreds: Effect of age of dam, year and month of birth, and sex of foal. J. Anim. Sci. 48:480.

NRC (1989): Nutrient Requirements of Horses (5 ${ }^{\text {th }}$ Revised Ed.) Nutrient Requirements of Domestic Animals. National Research Council. National Academy Press. Washington, D.C.

\section{J. D. Pagan}

S. G. Jackson

Kentucky Equine Research, Inc. Versailles, Kentucky 40383 S. Caddel

Hallway Feeds, Lexington, KY 40508 